UDC 821.161.1-Baltrush.21

DOI https://doi.org/10.32838/2710-4656/2021.4-3/05

Shcherbina $\boldsymbol{V} . \boldsymbol{V}$.

orcid.org/0000-0002-2717-3855

National Academy of the National Guard of Ukraine

\title{
LEXICO-SEMANTIC EXPRESSIVE MEANS AS A FEATURE OF YURGIS BALTRUSHAITIS' POETIC WORLD IN THE CONTEXT OF RUSSIAN SYMBOLIST POETRY
}

\begin{abstract}
The article is devoted to the analysis of the lexico-semantic expressive means in Yurgis Baltrushaitis' artistic world. The features of symbolist artistic thinking contributed to the creation of specific image system. The development of the lyrical plot, in which concrete notions were replaced by abstract images and ideas, required the use of expressive means aimed at symbolic transformation of the world.

The purpose of the article is to reveal the features of lexico-semantic expressive means and stylistic devices in Baltrushaitis' artistic world, to outline the similarity and difference in their use in early poet's works and in the lyrics belonging to later periods of Baltrushaitis 'creative activity. Baltrushaitis' artistic world consists of images, based on the parallel with nature, cosmos and the universe. Most of images and motifs are frequently repeated and seem to be constant in poet's works.

It is proved in the article that simile, connected with the motif of the continuous motion, appears to be one of the most productive and frequent expressive means in poet's artistic world. Semantically similes can be divided into several groups. The similes, denoting time and time attributes are especially numerous. They reveal the poet's perception of the time concept. Time in Baltrushaitis' lyrics is developed in a circular way: day - hour-instant - day. All periods of time in the poetry are related to the image of eternity. The motifs of ascent and descent reflect the most significant periods in the lyrical character's life. These motifs are connected with the problem of true being and the necessity of inner development and spiritual seeking.

It is shown that the similes connected with the ascent are aimed at emphasizing the emotional and spiritual completeness of the lyrical character's life. The similes, describing the lyrical character's descent, have opposite meaning and are aimed at reflecting man's feeling of dismay and fatality. In late Baltrushaitis'lyrics the similes, summarizing the lyrical character's spiritual seeking, are based on the comparison of time and time attributes with the words denoting concrete notions.

In Baltrushaitis' lyrics words belonging to opposite semantic sphere are easily united revealing man's intensive inner life and controversial feelings and emotions. Antithesis uniting contrasting concepts appears to be the important expressive means as well as the compositional centre of many Baltrushaitis'poems.
\end{abstract}

Key words: simile, antithesis, image, lyrics, artistic world.

Formulation of the problem. The Russian symbolists are known to create a new type of artistic thinking, based on worshiping poetic word and new, in some way iconic, attitude to the poetic language, capable of mythopoetic transformation of reality. The creators of new literary trend worked out the manner of writing that differed a lot from those existing before. The new manner gave the opportunity to depict the world of dream as well as to show the slightest movements and changes of life in order to create the mood necessary for the artist. As a result the readers' imagination could perceive the author's message. In their eagerness to show the mysterious world of ideas, the symbolists were looking for universal regularities. The expressive means and stylistic devices became in the Russian symbolists' lyrics the method of transforming the ordinary life and showing the way to the ideal world of harmony.

Philosophic and aesthetic views of the Russian symbolists determine both the originality of their poetics and specific features of the verse systems. The new literary movement, created at the turn of the centuries, reflected the main moods and worries of the epoch. The apprehension of deep public crisis as well as the expectation for something new was reflected in literature. The picture of literary development at the end of the 19-th - beginning of the 20-th century seems to be rather complicated and controversial. Each poet was looking for unique 
way of realization. It was the time when new, both realistic and unrealistic artistic movements appeared. They were different by nature and were based on various and often opposite ideological and artistic principles. Different character of literary phenomena, unlikeness of aesthetic programs proved to be the signs of transition era in the world literary process. The Russian symbolists created both the new art and the new literary school with the original vision of poetic language aimed at recreating its original magic destiny. The symbolists worked out the new manner of writing which allowed them to depict the world of dream and spiritual concentration. The concept of the poetic image was changed and it caused the use of specific expressive means suitable to express both intensified emotions and abstract ideas. The expressive means of the language and all kinds of stylistic devices became for the Russian symbolists the way of symbolic transformation of the world.

The researcher N. Kozhevnikova points out: "The masterly use of tropes allowed the representatives of the new art to show the specific movement of artistic images without mixing with reflected reality. Each word got additional meaning and became a symbol and each symbol became a trope itself" [4, p. 25]. The original language consisting of words-symbols appeared to be the only reality their philosophic views based on. The words-symbols embodied the essence of the world, the mysterious unity of its sensual manifestations and supersensible revelations. The Russian symbolists contributed to the world literature original themes, new ideas, motifs and images which required specific means of embodiment. The stylistic devices helped symbolists to express the slightest shades of emotions and approach the unearthly world of harmony. Based on combination of incompatible notions, the tropes in the symbolist artistic world were aimed at transforming ordinary things into something ideal and harmonious.

Literature review. Russian symbolism is an international phenomenon. Yurgis Baltrushaitis seems to be some kind of iconic figure in the history of Russian-Lithuanian relations at the end of the XIX-beginning of the XX century. His creative output isn't very significant in volume but seems to be integral and original and is based on the assimilation of two cultures. The poet joined the symbolist movement when it had already become the powerful literary trend. For his contemporaries Baltrushaitis was the brilliant expert on Scandinavian literature and active promoter of Modernist literature. Poet's lyrics and critical reviews occupy modest place in the symbolist art but in many aspects reproduce the evolution of this literary movement. Baltrushaitis' poems and articles remained beyond the critics' attention until the 1980-s. The only book, devoted to the poet's life and creative activities, belongs to Lithuanian researcher V.Dauyetite [3], who takes into consideration Baltrushaitis' personality, his relations with Russian symbolists of older and younger generations, cooperation in symbolist editions "Vesy" and "Scorpion". V. Dauyetite emphasizes the dual character of Baltrushaitis as a poet, his belonging to the Lithuanian and the Russian imperial cultures, whose features can be observed in two artistic worlds, which seem quite different.

B. Merzhvinskite [7], another Lithuanian researcher, paid special attention to the connection of poet's critical reviews and his lyrics. In her opinion, Baltrushaitis' critical works give the opportunity to determine his literary orientation in a more proper way. The reviews and articles create the certain unity with Baltrushaitis' poetry. The researcher points out, that "the main poetic themes, images and lyrical tone often coincide" [7, p. 130].

The studies of the Lithuanian researchers contributed to the further analysis of Baltrushaitis' artistic world in the articles of O. Cramar [5], T. Shekhovtsova [9], O. Kushlina [6]. The scholar L. Sproge [8] takes into consideration the features of chronotope and its connection with the means of creating poetic images.

S. Gardzano [2] gives the detailed characteristic of the expressive means and stylistic devices of several Baltrushaitis' poems, devoted to Italian history, culture and traditions.

In spite of increasing interest to Baltrushaitis'poetry and his personality, the researches, devoted to his creative activity, are not numerous and are connected with the limited number of issues. The modern state of the science shows that the heritage of artists who, didn't define the leading symbolist tendencies but played significant role in that movement, isn't properly analyzed. In many aspects it concerns Yurgis Baltrushaitis, whose poetry is seen as the integral part of the literary context of the time. The problem of his poetry correlation with the Russian symbolism isn't studied enough. The analysis of existing works prove that the complete studies of Baltrushaitis' artistic world, in general, and expressive means of his poetry, in particular, haven't been done.

The purpose of the article is to reveal the features of lexico-semantic expressive means and stylistic devices in Baltrushaitis' artistic world, to outline the similarity and difference in their use in early poet's works and in the lyrics belonging to later 
periods of Baltrushaitis' creative activity. The analysis of lexico-semantic and syntactic stylistic devices in Y. Baltrushaitis' poems will give the opportunity to reveal the structure and features of his poetics in its interconnection with other symbolists' seeking. The results of the research will help to define the nature and features of Baltrushaitis' artistic method and his position in the history of the Russian Symbolism and in the 20-th Century Literature.

Outline of the basic material. Characterizing the poetic mood and impressions, made by Baltrushaitis' poems V. Dauyetite points out that "his lyrics is filled with the atmosphere of quietness, concentration, spiritual dismay, noble and genuine sadness" [3,p. 166]. Philosophic wisdom, genuineness of feelings and severe veracity of Baltrushaitis' works contributed to his choice of expressive means, suitable for creating specific thoughtfulness and constant emotional strain of the poetic context. In poet's artistic world the concept of love doesn't have absolute poetic value and isn't regarded as the source of lyrical experiences. Baltrushaitis never wrote about intimate sufferings or deeply personal feelings. The spiritual seeking or psychological state, controlled by philosophic idea, became the basis of poet's artistic world. The poet turned philosophic ideas into some kind of belief and inner necessity. In many Baltrushaitis' works feelings and emotions can be seen from aside from the point of view of a thinker, a philosopher of nature. Avoiding speaking about love, the poet came to the certain idealization of nature and cosmos. In V. Dauyetite opinion, "Baltrushaitis' poetry is based on subjective relations between the personality and the universe but the components of the outer world are merged into poet's mood, experience and turned into the new artistic reality. The transformation of reality into artistic one occurs by means of lyrical perception" [3, p. 168].

The context of the whole Baltrushaitis' lyrics appears to be especially significant as it creates the certain emotional strain at each separate poem. As a result the abstract philosophic idea is combined with the specific lyrical mood. The poet seems to look for correspondence between human feelings and the universe itself. Baltrushaitis' artistic world consists of images based on the parallel with cosmos and the universe. Most of poetic images are frequently repeated and seem to be constant ones. The number of major images is not big but combinations they form with each other are numerous and original. The most typical images of space, time, Eternity, sea, drop, light, steps, dream, prayer, shade, circle, corn, sickle, stick, heart are used for creating expressive means and stylistic devices in Baltrushaitis' lyrics.

Simile appears to be one of the most frequent stylistic devices in poet's artistic world. The researcher V. Dauyetite points out: "The basis of similes is nature and universe. Baltrushaitis' similes look like the true search of connections between man and the earth, like bridges which help the poet to overcome the abyss, separating them" [3, p. 190].

The similes are not steady structures. They are movable and dynamic. Let's consider the way the similes develop in Baltrushaitis' artistic world. It is known that symbolists were likely to perceive all their works as the entire indivisible text. Baltrushaitis' two books of poems seem to be the story of the same lyrical character. In the mystery of being man is viewed to be the pilgrim and his life resembles the journey.

The idea of constant movement forms the basis of the lyrical plot of books of poems as well as of most verses. This idea is expressed with the help of expressive means and stylistic devices. The way of the lyrical character starts on bright spring morning. $\mathrm{He}$ admires the world around him. In early poems the similes are used to show the man delightfully worshiping nature. Nevertheless, the poet emphasizes, that man is enthusiastic but passive observer who hasn't faced the discord with the nature.

"Piruyu, kruzhus na piru svetovom, / Kak iskra $v$ pozhare zhyvom... / Pred chudom sverkania bessmertnykh zarnits / Ya, smertnyy ne padayu nits" ("Rassvetnyye volny kachayut ladyu") [1, p. 33].

The lyrical character believes that he'll be able to cognize the universe and to reach the world of harmony. He perceives himself as the integral part of world circulation. The first group of similes in early poems are based on comparison of two gigantic images: "Raskrylis dali znoynyye, / Kak bezdny siney tmy..../ Ya slyshu vikhri stroynyye / Poyushchiye psalmy" ("V gorakh") [1, p. 38].

"Bozhiy mir dlya nas - kak more.../ My na tyomnom beregu" ("Na otmeli") [1, p. 59].

The lyrical character feels the connection with the nature but perceives it not as the reality but as some unattainable ideal. The similes appear to emphasize the sovereignty and immutability of space, which seems boundless and powerful. The lyrical character is impressed by the immensity of the world. Man enthusiastically observes the life of nature which is perceived as the part of the universe. The atmosphere of newness as well as visual impression is created with the help of similes.

The second group of similes contains comparison of the world and the outer space with other nature 
images or abstract concepts. Let's have a look at some examples of similes belonging to this group. "V rosistyy krug zemli, raskryvsheysya, kak chasha" ("Utrenniye pesni”) [1, p. 32].

"V tishi nebes raskrylos mirovoye, / Gde bleshchet yarche plamya bytiya, / Gde ves prostor - kak prazdnestvo zhivoye!" ("Na poroge nochi”) [1, p. 77].

"Sladko serdtsu byt na svete! / Vse zhe mir - kak vechnyy lug" ("Grokhot miga") [1, p. 83].

"I snova dukh, kak piligrim opalnyy, / Voskhodit v khram prorocheskoy Molvy, / Gde shir zemli - kak zhertvennik venchalnyy / Pod zvezdnym krovom Boga sinevy" (Voskhozhdeniye") [1, p. 105].

The lyrical plot is based on the idea of continuous movement. The lyrical character is regarded as the integral part of this global motion. The image of space develops in parallel with the spiritual development of lyrical character. At the beginning of his way the world looks friendly and comprehensible.

"S bezmernym likovaniyem / Smenyayutsya chasy, / Ves mir obyat siyaniyem, / Chto kapelka rosy!" ("V gorakh") [1, p. 38]. The simile is aimed at expressing hero's admiration and delight he feels worshiping nature and enjoying its beauty and power.

The way of the lyrical character goes from serene happiness towards the tragedy of understanding the impossibility to reach the heavenly world as well as to acquire harmony and spiritual comfort. The moment of happiness, short and unreliable, is followed by a new period in the life of the lyrical character. Man is in dismay and is in vain trying to look for the unity with nature. Man's suffering is deep, severe and restrained. We can notice that similes change semantically. They are aimed at emphasizing indifference and hostility of the space as well as the inner drama of the lyrical character: "Nash bozhiy mir - kak chuzhdaya obitel, / Ugryumyy khram iz drevnikh mshistykh plit" ("Vecher") [1, p. 76].

In nature everything is repeated, all phenomena are cyclical. The author underlines the impersonal greatness of nature, its invincible steadiness which makes the lyrical character, realizing the fragility of his own life, look for eternity and durability in nature. "I v mertvom prostore, / Nad seroy dorogoy, / Gde glukho sedeyet trava, / Bezmolvno i strogo, / Kak sonnoye more, / Raskryla svoy mir sineva" (Put k sineve") [1, p. 139].

In V. Dauyetite's opinion, "the similes in Baltrushaitis' artistic world have metaphoric character. At the same time similes are viewed as the way of seeking the connections between man, nature and the universe. Metaphor appears to be the formula and confirmation of the found connection" [3, p. 190].
The similes denoting time, its attributes and characteristics of different time periods of human life are numerous both in Baltrushaitis' early poems and in his late lyrics. This feature of poet's artistic world can be also explained by the symbolist tendency to cycle creating. As a result each poem looks structurally completed as well as open and ready to get new semantic connections. In Baltrushaitis' lyrics poems seem to be components of the whole text community reflecting the certain episode in the development of the lyrical plot. The similes are connected with the motif of the eternal motion which is regarded as the organizing center of the book of poems. The symbols of four seasons are related to the poetic cycles in each collection of poems. The plot of each poetic cycle develops according to its inner laws, creating the movement of poetic thought from one period of the lyrical character's life to another one. The similes, characterizing the beginning of the hero's way, have positive meaning. Day seems to be the most important time period and corresponds to the youth of the lyrical character.

"V rosistyy krug zemli, raskryvsheysya, kak chasha, / Chto pennoye vino, struitsya znoynyy den" ("Utrenniye pesni”) [1, p. 32].

"Lyetsya, kak plamya, $v$ vody / Siniy, radostnyy den - / Kholit zemnyye vskhody" ("Krug Vekovechnyy") [1, p. 106].

The world seems to be waiting for being explored and discovered. All the phenomena are subordinated to the universal aspiration. The similes are aimed at creating the special emotional atmosphere. In the poetic context time gets colouring and becomes tangible.

Hour corresponds to the next period in lyrical character's spiritual growth. At first, hour seems to be light, movable and less tangible. The comparison of hour with airy and water elements is aimed at revealing the hero's specific emotional state. Such similes help to create the general atmosphere of flight. The man views himself as integral part of the earthly world. All the phenomena of nature are connected and subordinated in their common aspiration to the far heavenly world of harmony. The lyrical character shares the feeling of global unity and admires it. The true artist's duty is to comprehend and appreciate the slightest movements and manifestations of nature. Art and nature are inseparable as only together they can give man the opportunity to experience the mysteries of all creation. "Moy chas, kak oblako plyvyot" ("Bespechnost") [1, p. 39]. "Skvoz lyogkiy son dushi, / Plyvyot-struitsya chas obyknovennyy, / Kak dym v tyshi" ("Chas Obyknovennyy") [1, p. 191]. 
Gradually hour acquires some fluidity and materiality. "Chas cheloveka podoben volne / Znayesh li, smertnyy v nochnoy glubinye, / Vstretiv molitvoy zvezdnuyu tish, / Chimi ustami ty govorish?" ("More i kaplya") [1, p. 199]. We can notice that time doesn't seem to be as kind, generous and carefree as it was at the beginning of the lyrical character's pilgrimage. In the poem "The Sea and the Drop" ("More i kaplya") the picture of night looks vast and dignified. Night is mysterious, serene and full of harmony. The lyrical character can't help thinking about God, the creator of the world harmony, the power, uniting people and nature. The time of human life is given and determined by God. The Biblical motifs can be heard in the poem. The lyrical character's pray is spiritual comprehension of eternity. Man is longing to reach the world of harmony and only God may lead him through the prehistoric chaos to the beginning of creation.

"To yav gremit, to, osenennyy snami, / Kak dymnyy fakel, tleyet tikhiy chas.../ Ikh chereda raschislena ne name, / Ikh taynyy sled v dushe reshen bez nas!" ("Razdumye") [1, p. 156].

The simile based on the comparison with smoky torch gives the opportunity to see the way the time of human life moves and passes by. The torch is burning and the lyrical character is approaching the merciless death. In Baltrushaitis' artistic world the hour materializes and acquires more physical characteristics, such as volume, shape, direction.

"Chas - kaklegkaya strela... / Mig v nyom - budto vzmakh kryla... / Vspykhnul svet, I snova mgla!" ("Bystrotechnost") [1, p. 123].

The hour is personified, drifts away from the lyrical character and turns into mysterious creature which can rule and direct human life. The poet emphasizes the tragic position of man in the earthly world. The lyrical character's life may seem happy and light but it is always full of suffering and anxiety due to the transience of time and being.

"Dalshe, vse dalshe, vse glushe poyet / Skorbnyy i mernyy, otryvistyy zvon - / Shestviye Chasa v pustyne vremen" ("Mayatnik") [1, p. 98].

The continuous motion of time is the compositional center of the poem. The lyrical character is trying to reconsider his life and to enter into the dialogue with time which is embodied in the images of gloomy Captain of mysterious galley and symbolic Pendulum, which leads man to the dark abyss beyond time and space which seems to be man's only reality. The task of the true artist is to enlighten the chaos and to start a new living cycle. The motifs of ascent and descent as the most significant periods in the human life can be heard in the poem. These motifs are connected with the problem of true being and the necessity of inner development and spiritual seeking.

The similes, denoting time and time attributes, reveal the poet's perception of the time concept. In Baltrushaitis' lyrics time is not the form of objective reality or matter existence. The introduction to the eternity, which can be found in the present, appears to be the important guideline in poet's artistic world. The time perspective is getting narrower. The image of instant is seen to be the most significant as in the poet's opinion, the instant can help man to cognize the eternity and approach it.

"Mgnoveniya - kak molnii.../ V ikh smene Nemeyet vzdokh otdelnosti vo mne... / I v smertnoy dole vyshe net stupeni" ("Voskhozhdeniye") [1, p. 104].

Hours are alternated by instants which are inweaved into the eternity. The concept of instant in Baltrushaitis' artistic world is connected with the image of steps, which appear to be the attribute of lyrical character's ascent and descent, two main periods of his spiritual development. The steps and instants are seen as the measure of countdown. Similes, describing the image of instant, are used to work out the certain semantic benchmarks which contain either positive or negative characteristics of the lyrical character's surrounding.

"Vot lyutsya solnechnyye volny, - / Bayukaya zabvenno nas, / I kazdyy mig - kak kubok polnyy" ("Lish tot sred zvezd venchayet zemlyu") [1, p. 205].

"I mig, chto shumnaya volna, / U skal morskich, ne znaya sna, / Poyet molitvennyye ody" ("Pismo") [1, p. 218].

In these poetic contexts the similes are used to emphasize the emotional and spiritual completeness of the lyrical character's life. The man's ascent is the way of creation and gaining supreme values.

The similes, characterizing the lyrical character's descent, haveoppositemeaningandareaimedatreflecting man's feeling of dismay and fatality: "Prokhodit zhizn v tomlenii I strakhe... / Bezmeren put... / I kazhdyy mig, kak shag k ugryumoy plakhe, / Szhimayet grud" ("Chernoye solntse") [1, p. 90]. "Zabvennyy mig i srok trevogi, / Stol chasto ostroy, kak igla" ("Chas izmeni tsvety solgali") [1, p. 202].

In Baltrushaitis' artistic world the tragedy of outer being is opposed to the richness and light of the human soul. The lyrical character can find charm in his longing.

"Chut vnyatno dyshit vecher pozdniy / Posledniy mig iz chasa rozni / Otstaloy iskroy dogorel" 
("Chudom teni") [1, p. 188]. The creative activity belongs to the heavenly world and is always directed up into the sky. The picture of night determines the tone of the narration which sounds like serene and majestic.

"Speshi zh rastorgnut Chudom Teni / Vsyu bol i gorech dolnikh slyez, / Kto v veshchiy chas nochnoy stupeni / Svoy zhrebiy k vechnosti voznes!" ("Chudom teni") [1, p. 189]. Great emotional strain awakens new forces and abilities in the human soul. Each emotional impression is considered, developed and turned into the regularity. The lyrical character's enriched by the experience of ascent and descent, is ready to start a new cycle of his spiritual seeking.

In late Baltrushaitis'lyrics the similes, summarizing the lyrical character's spiritual seeking, are based on the comparison of time and time attributes with the words denoting concrete notions.

"Tvoy kazhdyy chas - chto khleb pshenichnyy, / I s nim ty krepok, s nim ty - tsar... / A mne moy mig - krokha, sukhar, / Ne v meru zhestkiy, slishkom cherstvyy!" ("Vyacheslavu Ivanovu") [1, p. 266].

Time materializes and becomes the main necessity of the lyrical character. The comparison with the stale crumb of bread emphasizes the value of time and shows how little time of human life is left. In the poem "Premonition" ("Predchuvstiviye") the lyrical character perceives his time not as impersonal regular cycle but as the way of a personality. "Amin! Tsvetyot venets ternovyy / Vselennoskoy Vechere otsel, / Blagoslavi svoi okovy / I budet vremya - kolybel..." ("Predchuvstiye") [1, p. 271]. Man is trying to comprehend wisdom of God, of Higher forces, to realize the life of nature and approach the ideal world of harmony. Wisdom of God appears to be majestic and magnificent. Wisdom of man is in understanding his dramatic lot and accepting it. The Biblical allusions are used to express the idea of soul immortality and eternity of life.

We can notice that the image of time develops in a circular way: day - hour - instant - day. All periods of time in Baltrushaitis' poetry are related to the image of eternity. The lyrical character is seen as a pilgrim travelling about the vast endless space. The expressive means in poet's artistic world are aimed at showing and characterizing the periods of man's way corresponding to the stages of his spiritual growth.

Another stylistic device, important for understanding Baltrushaitis' artistic world, is antithesis. In N.Kozhevnikova opinion, "antithesis in the poetry of early XX century turns into one of the central principles of word usage, connected with features of perception of the world" [4, p. 38]. Antithesis and oxymoron are used to describe man's inner world as well as the whole universe presented as the unity of opposing forces.

In Baltrushaitis' artistic world most of images have own opposition pairs: life - death, light - shadow, day - night, high tide - low tide, heat - cold, midday midnight, rumble - silence. Such pairs of antonyms form the basis of antithesis. The oppositions don't necessarily include antonyms proper. The feature of Baltrushaitis' artistic world is in grouping words which are not considered to be antonyms: sea-drop, blossom - ash, beggar-prince, spring - snowstorm, wings - chains, sigh - grown, whirl - dream. Such oppositions are not unambiguous as they are frequently repeated and are used for creating a number of images. The oppositions occupy the whole poet's artistic system and can be explained and understood completely only in its context.

The feature of Baltrushaitis' poetic philosophy is desire for integrity which can be obtained by uniting extremes. The world for Baltrushaitis doesn't seem to have final outlines. All the objects and phenomena are born, die and reborn anew every day. According to the philosophic tradition originated from Neoplatonism, the universe is represented as the mutual transition of two realities the overturned cone of divine light and the cone of darkness directed upwards. Two significant images of day and night are connected with this philosophic tradition.

"Sluchayny sny i pyl uma ... / Obmanchiv mig i podvig let ... / Ne znayet den, chto budet tma, / $\mathrm{Ne}$ verit noch, chto budet svet!" ("Elegiya") [1, p. 173]. The images of day and night are rather productive in Baltrushaitis' artistic world. They are presented as two multidirectional essential forces. As it can be seen in the poem "Elegy" ("Elegiya") they are not opposed in time. Day disappears when night comes and night goes away as day sets in. The world is seen as the unity of opposing notions. Contrasting phenomena are alternated according to the period of lyrical character's life story. Such alternation, expressed by bright antitheses, is reflected in the lyrical plot of many Baltrushaitis' poems.

"Ya svetloy doli znal nemalo, / I trudnoy skorbi vedal mnogo ... / Ne raz, ne raz vesna pylala - / Ne raz metel dymilas strogo" ("Cheredoyu") [1, p. 157]. The antitheses in this poetic context are used to show various episodes of man's life, his negative and positive experiences. "Chas gordoy sily vel istomy... / Smenyal nevolyu chas svobodnyy.../ I zhdal ya schastya po-pustomu, / I chakh i tsvel poocheredno" ("Cheredoyu") [1, p. 157]. The 
necessity of both happy and unhappy moments is emphasized in the poem. The presence of opposing states makes the lyrical character's life exciting and complete.

In Baltrushaitis artistic world the antithesis is often based on time images, which can be coded in the combination beginning-end. "S molitvoy Solntsa vstretil ya zaryu / S molitvoy svetu provozhayu den - / Po mere chasa bytiya goryu, / Po mere roka pogruzhayus v ten" (“Osennyaya pesnya”) [1, p. 239]. Time in this poetic context is seen in its vastness and fluidity. Every day is followed by the endless number of days.

Time antitheses embody the flow of time itself. "Polden ranit, polnoch lechit... / Polnoch polden - chet i nehet... / Chas dobychi, chas poteri, / Vse po prikhoti i mere... / Bylo laskoy, stanet bolyu" ("Pesnya") [1, p. 235]. The lyrical plot of the poem includes a number of vivid pictures, expressed by the antitheses. They make the narration dynamic and logical. Short completed phrases are used to emphasize rhythm. The antitheses, expressed by short word combinations or phrases, seem to count days, hours and instants, which are repeated and combined in one tissue.

"Grokhot miga... tish stoletiy... Veshniy chas, voskresshiy vdrug" ("Grokhot miga") [1, p. 238]. "I pylnyy dol, i vysi gor, / I chas vesny, i chas sedoy / Spletayutsya v odin uzor / Nepostizhimoy cheredoy" ("Elegiya") [1, p. 173]. In the poem "Elegy" all barriers between time periods disappear and time is united with space. The lyrical character perceives time as one flow, in which instant is equal to eternity. Time is not segmented any longer and turns into space category. The larger the space becomes the shorter the human life gets. The antithesis dusty valley - mountain peaks contains the opposition of top and bottom. In Baltrushaitis' artistic world these images symbolize rise and fall.

In L. Sproge opinion, "antithesis in Baltrushaitis' artistic world is not just the expressive means and the stylistic device, it is also the way of compositional formation of the poem" [8, p. 32]. The lyrical plot in Baltrushaitis' poems is often developed by means of combining contrasting notions. The lines of thoughts and emotions move in parallel way and create the common poetic situation.

"Ot udela skudosti k izbytku, / Ot rasstsveta $v$ prakh i snova $k$ tsvetu - / Ty vlechesh na pirshestvo $i$ pytku/Poukladuzhizni iobetu"("Chasys kukushkoy") [1, p. 244]. The antithesis in Baltrushaitis' lyrics accords to poems specific symmetry and rhythmic balance. The images of continuous motion, repetition and alternation are dominating in poet's artistic world.

"To opyanyonnyy sinevoy / Pletus stezyoyu kochevoy... / To vnov, v dokuchnoy polumgle, / Vlachu svoy zhrebiy na zemle... / Iz sveta $v$ ten, iz teni $v$ svet, / Idu, svershaya svoy zavet" ("Iz teni v svet") [1, p. 159]. The antitheses, based on the images fixing motion acquire philosophic meaning. The lyrical character is aware of his weakness and fragility of earthly being, he isn't trying to win time. Man in Baltrushaitis' lyrics engages in the endless dialogue with time and goes on walking. Antithesis denoting time in poet's artistic world is used to express the opposition of instant to eternity. This opposition is connected with the theme of true artist's severe duty. The value of human life is determined by man's spiritual seeking and moral choice.

Conclusions and prospects of further investigation. The features of symbolist artistic thinking contributed to the creation of specific image system. The development of the lyrical plot from concrete notions to ideal concept required the use of expressive means aimed at symbolic transformation of the world. Baltrushaitis' artistic world consists of constantly repeated images, based on the parallel of human life with nature, cosmos and the universe.

Simile, connected with the motif of the continuous motion, appears to be one of the most productive and frequent expressive means in poet's artistic world. Time similes are especially bright and numerous. The motifs of ascent and descent reflect the most significant periods in the lyrical character's life. The similes connected with the ascent are aimed at emphasizing the emotional and spiritual completeness of the lyrical character's life. The similes, characterizing the lyrical character's descent, have opposite meaning and are aimed at reflecting man's feeling of dismay and fatality. In late Baltrushaitis' lyrics the similes, summarizing the lyrical character's spiritual seeking, are based on the comparison of time and time attributes with the words denoting concrete notions

In Baltrushaitis' poetry words belonging to opposite semantic sphere are easily united revealing man's intensive inner life and controversial feelings and emotions. Antithesis uniting contrasting concepts appears to be the important expressive means as well as the compositional centre of many Baltrushaitis' poems.

The further research in this area is to be devoted to the analysis of archetypes in Yurgis Baltrushaitis' artistic world in the context of the Russian Symbolist poetry. 


\section{References:}

1. Балтрушайтис Ю. Дерево в огне. Вильнюс : Vaga, 1983. 319 с.

2. Гадзано С. Стихотворение Ю.Балтрушайтиса «Привет Италии». Литературное обозрение. 1999. № 4. С. 59-69.

3. Дауетите В. Юргис Балтрушайтис. Вильнюс : Vega, 1983. 326 с.

4. Кожевникова Н. А. Словоупотребление в русской поэзии начала XX века. Москва : Наука, 1986. $253 \mathrm{c}$.

5. Крамарь О. Философско-эстетическая функция эпиграфа в поэтике русского символизма. Русская литература и философия: Постижение человека. Липецк : ЛПГУ, 2002. С. 179-189.

6. Кушлина О. Юргис Балтрушайтис. Русская поэзия «Серебряного века». 1890-1917. Антология. Москва : Наука, 1993. С. 228-238.

7. Мержвенските Б. А. Балтрушайтис и Блок. Тема художника в эстетической концепции младосимволистов. Из истории реализма конца ХІХ - начала ХХ вв. Москва : Изд-во МГУ, 1986. С. 123-138.

8. Спроге Л. Юргис Балтрушайтис: от «книги стихов» к «дилогии». Серебряный век русской литературы:: проблемы, документы. Москва : Изд-во МГУ, 1996. С. 24-34.

9. Шеховцова Т. Колокольная перекличка (Ю. Балтрушайтис и Б.Чичибабин). Материалы Чичибабинских чтений 2000-2002. Харьков, 2002. С. 101-109.

\section{Щербина В. В. ЛЕКСИКО-СЕМАНТИЧНІ ВИРАЗНІ ЗАСОБИ ЯК ОСОБЛИВІСТЬ ПОЕТИЧНОГО СВІТУ ЮРГІСА БАЛТРУШАЙТІСА В КОНТЕКСТІ РОСІЙСЬКОЇ СИМВОЛІСТСЬКОЇ ПОЕЗЇ̈}

Статтю присвячено аналізу лексико-семантичних виразних засобів у поетичному світі Юргіса Балтрушайтіса. Особливості художнього мислення символістів сприяли створенню своєрідної системи поетичних образів. Розвиток художнього сюжету, у якому конкретні поняття замінялися на абстрактні образи та ідеї, потребував використання виразних засобів, начілених на символічне перетворення світу.

Мета статті - визначити особливості лексико-семантичних виразних засобів та стилістичних прийомів у художньому світі Юргіса Балтрушайтіса та окреслити схожість та відмінність у їх використанні у ранніх віршах поета та у ліриці, яка належить до більш пізнього періоду творчості Балтрушайтіса. Художній світ Балтрушайтіса містить образи, які утворюються на основі паралелі з природою, космосом та всесвітом. Більшість образів та мотивів часто повторюються та є стійкими у творчості поета.

Доведено, що порівняння, пов'язане із мотивом постійного руху є найбільш продуктивним та частотним виразним засобом у художньому світі поета. За семантичною структурою порівняння можуть бути розподілені на кілька груп. Порівняння на позначення часу та його атрибутів є особливо чисельними. Вони розкривають специфіку сприйняття ідеї часу поетом. Час у ліриці Балтрушайтіса розвивається по колу: день - час-миттєвість - день. Усі часові періоди вбачаються спорідненими образу вічності.

Мотиви підйому та спуску віддзеркалюють найбільш значущі періоди у житті ліричного герою. Ці мотиви пов'язані із проблемою істинного буття та необхідності внутрішнього розвитку та духовних шукань.

Показано, що порівняння пов 'язані із мотивом підйому мають за мету висвітлювати ідею емоційної та духовної иілісності життя людини. Порівняння, які описують спуск ліричного герою, мають протилежне значення та є начіленими на відтворення почуття збентеження та приреченості. У пізніх віршах Балтрушайтіса підсумовуються результати духовних пошуків ліричного героя, $i$ час та його атрибути порівнюються із конкретними поняттями.

Уліриці Балтрушайтіса слова, якіналежать до протилежних семантичних сфер, легко об 'єднуються та використовуються для відтворення інтенсивного внутрішнього життя людини та суперечливих почуттів та емоцій. Антитеза, яка об'єднує контрастні поняття, є не тільки важливим виразним засобом, але й композичійним центром багатьох віршів Балтрушайтіса.

Ключові слова: порівняння, антитеза, образ, лірика, художній світ. 